\title{
Minat Melakukan Pencatatan Akuntansi Melalui Pendidikan, Umur Usaha, Dan Komitmen Organisasi Pada Industri Kecil Menengah Kabupaten Jepara
}

\author{
Yanto 1, Shalihul Aziz Widya Iriawan 2, dan Fatchur Rohman ${ }^{3}$
}

${ }^{1}$ Universitas Islam Nahdlatul Ulama, Jl. Taman Siswa, Kabupaten Jepara, Jawa Tengah, 59451, Indonesia ${ }^{2}$ Universitas Islam Nahdlatul Ulama, Jl. Taman Siswa, Kabupaten Jepara, Jawa Tengah, 59451, Indonesia ${ }^{3}$ Universitas Islam Nahdlatul Ulama, Jl. Taman Siswa, Kabupaten Jepara, Jawa Tengah, 59451, Indonesia

\section{ABSTRACT}

The purpose of this study is to analyze the interests of accounting records through education, age of business, and commitment. The sample of research is 89 IKM in Jepara regency, sampling technique using random sampling. Analyzer uses multiple regression, hypothesis test, and coefficient of determination. The results of the analysis is known to have a significant influence on the importance of accounting records, evidenced by testing the hypothesis $t$ is the value of sig. 0.001. Organizational commitment has a significant influence on interest in accounting records, evidenced by testing the hypothesis $t$ is the value of sig. 0,000. Age of business does not have a significant influence between the interest to perform accounting records, evidenced by testing the hypothesis $t$ is the value of sig. 0.740 .

Keywords: accounting recording, education, age, and commitment

\section{PENDAHULUAN}

Pencatatan akuntansi sebagai langkah untuk mengelola dan mengendalikan harta perusahaan ini sesuai Firman Allah SWT dalam surat Al-Munafiqun ayat 9 : (Isgiyarta, 2009)

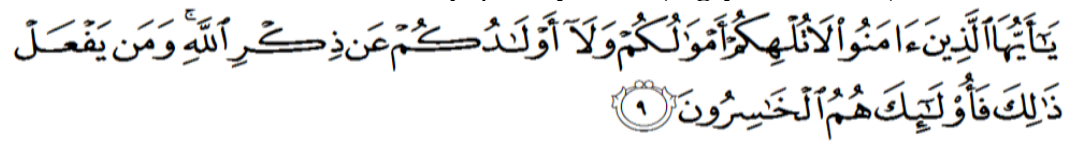

Artinya:

"Hai orang-orang yang beriman, janganlah harta-hartamu dan anak-anakmu melalaikan kamu dari mengingat Allah. Barang siapa yang membuat demikian maka mereka itulah orang-orang yang rugi. "(Q. S. Al-Munafiqun: 9)

Berdasarkan surat Al-Munafiqun ayat 9, berarti supaya kita sebagai manusia tidak mengalami kerugian baik di dunia maupun di akhirat, maka sebaiknya kita melakukan pengelolaan yang baik terhadap harta yang diberikan Allah SWT kepada kita yaitu dengan cara melakukan pencatatan akuntansi. Secara lebih spesifik, pencatatan akuntansi memfasilitasi untuk mengevaluasi sejauh mana harapan akan keuntungan terpenuhi dengan menghitung keuntungan dari transaksi yang sudah terjadi dan mencari potensi keuntungan untuk transaksi berikutnya yang dilakukan usaha kecil tersebut (Waymire, 2009).

Usaha kecil merupakan salah satu sub sektor kegiatan ekonomi yang memegang peranan penting dalam memperkuat struktur ekonomi secara makro. Di Amerika Serikat, usaha kecil membayar 44,3\% dari total gaji di sektor swasta, mempekerjakan separuh dari seluruh tenaga kerja di sektor swasta, dan menciptakan 60 \% sampai 80\% lapangan kerja baru selama satu dekade terakhir, (US Small Business Administration). Di Indonesia sendiri, usaha kecil mampu menyerap $88 \%$ tenaga kerja, memberikan kontribusi terhadap produk domestik bruto sebesar $40 \%$, dan mempunyai potensi sebagai salah satu 
sumber penting pertumbuhan ekspor, khususnya ekspor non migas (Indonesia Small Business Research Center) (Hanum, 2013). Mengingat besarnya kontribusi usaha kecil terhadap struktur ekonomi secara makro, maka industri kecil menengah (IKM) yang ada perlu perhatian khusus supaya dapat berkembang dan menopang atau memperkuat struktur ekonomi secara makro. Perhatian khusus tersebut seperti contohnya dalam pencatatan akuntansi. Banyak faktor yang dapat mempengaruhi pengusaha kecil untuk melakukan pencatatan akuntansi, yaitu pendidikan (Dewi, dkk. (2017), umur usaha (Halim, 2013), dan komitmen (Ratifah \& Ridwan, 2012).

Pendidikan dapat mempengaruhi seseorang dalam melakukan pencatatan akuntansi bagi perusahaannya karena pendidikan dapat memberikan pengetahuan yang semakin banyak, dan dengan pengetahuan yang dimiliki tersebut akan merubah pemahaman untuk sesuatu yang lebih baik, sehingga pendidikan dapat mendorong seseorang untuk melakukan pencatatan akuntansi supaya dapat mengetahui kondisi perusahaan yang sedang dijalankan dan bermanfaat untuk melakukan pengendalian. Selain pendidikan, umur perusahaan dapat mempengaruhi seseorang dalam melakukan pencatatan akuntansi bagi perusahaannya karena dengan lamanya perusahaan berdiri maka kegiatan atau transaksi yang dilakukan akan semakin banyak, dan kemampuan otak untuk mengingat juga berkurang, sehingga akan mendorong perusahaan untuk melakukan pencatatan akuntansi. Komitmen juga dapat mempengaruhi minat dalam melakukan pencatatan akuntansi. Komitmen adalah rasa empati dari diri anggota organisasi, yaitu pimpinan sampai dengan karyawan untuk memberikan dukungan terhadap perubahan yang dilakukan perusahaan. Jadi apabila suatu perusahaan memiliki komitmen untuk melakukan pencatatan akuntansi supaya perusahaan berkembang, akan didukung oleh seluruh karyawan selama kegiatan tersebut bermanfaat (Ratifah \& Ridwan, 2012). IKM di Kabupaten Jepara sebaiknya melakukan pencatatan akuntansi semuanya, karena dengan akuntansi perusahaan dapat memiliki perencanaan yang matang dan perusahaan dapat dikendalikan dengan baik dan akhirnya perusahaan dapat berkembang dan berani bersaing dengan perusahaan besar yang ada di Indonesia bahkan dengan perusahaan Luar Negeri.

IKM di Kabupaten Jepara berkembang, akibatnya yang sejahtera tidak pemilik atau pimpinan saja, tetapi karyawan juga akan sejahtera, bahkan perekonomian secara makro di Jepara khususnya dan Indonesia pada umumnya juga akan semakin kuat. Tujuan penelitian untuk menganalisis minat melakukan pencatatan akuntansi melalui pendidikan, umur usaha, dan komitmen pada IKM Kabupaten Jepara.

\section{METODE}

Penelitian dirancang sebagai penelitian kausal dengan pendekatan kuantitatif. Menurut Sugiyono (2011), penelitian kausal adalah hubungan yang bersifat sebab akibat, jadi di sini ada variabel independen (variabel yang mempengaruhi) dan variabel dependen (variabel yang dipengaruhi). Peneliti menggunakan desain penelitian kausal untuk mengetahui pendidikan, umur usaha, dan komitmen sebagai variabel independen berpengaruh terhadap minat melakukan pencatatan akuntansi sebagai variabel dependen. Pendidikan adalah sembarang proses yang dipakai individu untuk memperoleh pengetahuan atau wawasan, atau mengembangkan sikap ataupun keterampilan. (Encyclopedia Americana dalam Tarigan, 2009). Indikator untuk mengukur Pendidikan dibagi 4 tahap: Sekolah Dasar (SD), Sekolah Menengah Pertama (SMP), Sekolah Menengah Atas (SMA), Perguruan Tinggi (Diploma, S1, S2) (Tarigan, 2009). Umur Usaha adalah usia atau lamanya perusahaan beroperasi. (Sitoresmi dan Fuad, 2013). Umur usaha dihitung sejak awal pendirian usaha hingga penelitian ini dilakukan. (Sitoresmi dan Fuad, 2013). Komitmen adalah kemampuan dan kemauan untuk menyelaraskan perilaku pribadi dengan kebutuhan, prioritas dan sasaran organisasi (Natalie J Allen dan John P Meyer dalam Ratifah dan Ridwan, 2012). Komitmen diukur dengan: Affective commitment, Continuence commitment, Normatif commitment (Ratifah dan Ridwan, 2012). Minat melakukan pencatatan akuntansi adalah keinginan untuk melakukan pencatatan transaksi (kejadian) keuangan dalam buku-buku manual yang diperlukan seperti buku catatan, agenda atau bahkan dalam kertas-kertas lainnya (Karyawati dalam Halim, 2013). Minat 
melakukan pencatatan akuntansi diukur dengan : memahami akuntansi, mengetahui manfaat akuntansi, minat melakukan pencatatan akuntansi, dan melakukan catatan akuntansi (Halim, 2013).

Populasi penelitian ini adalah seluruh pengusaha IKM di Kabupaten Jepara sebanyak 18.695 orang. Ukuran sampel dihitung dengan rumus Slovin :

$$
n=\frac{18.695}{1+18.695(0,1)^{2}}=99,5=100
$$

Teknik sampling dalam penelitian ini menggunakan teknik proporsional sampling, dengan mengambil sampel dari proporsi masing-masing IKM.

Analisis data dalam penelitian ini menggunakan analisis secara kuantitatif, meliputi: uji validitas dan reliabilitas, uji asumsi klasik, analisis regresi berganda, pengujian hipotesis, dan koefisien determinasi.

\section{HASIL}

Hasil penelitian ini disajikan data terkait dengan variabel penelitian yang diperoleh dari penyebaran kuesioner. Dari penyebaran sebanyak 100 kuesioner, ada sebanyak 11 kuesioner yang tidak memenuhi proses pengolahan data, yaitu tidak semua kuesioner dijawab, dan tidak ada stempel perusahaan. Sehingga dalam penelitian ini, jumlah data yang dianalisis berasal dari 89 responden.

Analisis regresi berganda digunakan untuk mengetahui pengaruh pendidikan, umur usaha dan komitmen terhadap minat melakukan pencatatan akuntansi pada IKM Kabupaten Jepara. Hasil analisis regresi ditunjukkan sebagai berikut:

Tabel 1: Hasil Analisis Regresi Berganda

\begin{tabular}{|c|c|c|c|c|}
\hline \multirow{2}{*}{\multicolumn{2}{|c|}{ Model }} & \multicolumn{2}{|c|}{ Unstandardized Coefficients } & \multirow{2}{*}{$\begin{array}{c}\begin{array}{c}\text { Standardized } \\
\text { Coefficients }\end{array} \\
\text { Beta }\end{array}$} \\
\hline & & $\mathrm{B}$ & Std. Error & \\
\hline \multirow{4}{*}{1} & (Constant) & 9.135 & 1.760 & \\
\hline & PENDIDIKAN (EDC) & .867 & .255 & .335 \\
\hline & UMUR USAHA (AGE) & -.007 & .022 & -.033 \\
\hline & KOMITMEN ORGANISASI (COM) & .398 & .106 & .375 \\
\hline
\end{tabular}

Sumber : Data primer diolah dengan SPSS Statistics Version 20

Berdasarkan tabel 1 tersebut dapat dirumuskan persamaan regresi berganda sebagai berikut:

$\mathrm{IA}=0,335 \mathrm{EDC}-0,033 \mathrm{AGE}+0,375 \mathrm{COM}$

Nilai koefisien regresi untuk variabel Pendidikan (EDC) adalah 0,335, artinya pendidikan mempunyai pengaruh positif terhadap minat melakukan pencatatan akuntansi. Pengaruh positif di sini dapat dijelaskan yaitu apabila pendidikan pemilik IKM Kabupaten Jepara semakin tinggi akan meningkatkan minat para pengusaha untuk melakukan pencatatan akuntansi. Nilai koefisien regresi untuk variabel Umur Usaha (AGE) adalah -0,033, artinya umur usaha mempunyai pengaruh negatif terhadap minat melakukan pencatatan akuntansi. Pengaruh negatif ini dapat dijelaskan yaitu apabila umur usaha IKM Kabupaten Jepara semakin lama akan menurunkan minat para pengusaha untuk melakukan pencatatan akuntansi. Nilai koefisien regresi untuk variabel Komitmen Organisasi (COM) adalah 0,375 , artinya komitmen organisasi mempunyai pengaruh positif terhadap minat melakukan pencatatan akuntansi. Pengaruh positif di sini dapat dijelaskan yaitu apabila komitmen yang dimiliki IKM Kabupaten Jepara semakin tinggi atau kuat akan meningkatkan minat para pengusaha untuk melakukan pencatatan akuntansi. 


\section{Pengujian Hipotesis}

Untuk menguji praduga pengaruh antara pendidikan, umur usaha dan komitmen terhadap minat melakukan pencatatan akuntansi pada IKM Kabupaten Jepara menggunakan uji t dan uji F.

1. Uji Hipotesis $t$

Uji Hipotesis $\mathrm{t}$ digunakan untuk menguji praduga pengaruh antara pendidikan, umur usaha dan komitmen terhadap minat melakukan pencatatan akuntansi pada IKM Kabupaten Jepara secara parsial. Hasil uji hipotesis t ditunjukkan sebagai berikut:

Tabel 2.: Hasil Uji Hipotesis $\mathrm{t}$

\begin{tabular}{llrr}
\hline Model & \multicolumn{2}{c}{$\mathrm{t}$} & \multicolumn{1}{c}{ Sig. } \\
\hline \multirow{3}{*}{1} & (Constant) & 5.192 & .000 \\
\cline { 2 - 4 } & PENDIDIKAN (EDC) & 3.398 & .001 \\
\cline { 2 - 4 } & UMUR USAHA (AGE) & -.332 & .740 \\
\cline { 2 - 4 } & KOMITMEN ORGANISASI (COM) & 3.767 & .000 \\
\hline
\end{tabular}

Sumber : Data primer diolah dengan SPSS Statistics Version 20

Hasil uji hipotesis $\mathrm{t}$ didapat nilai sig. 0,001 $<a=0,05$, berarti pendidikan secara parsial mempunyai pengaruh positif signifikan terhadap minat melakukan pencatatan akuntansi pada IKM Kabupaten Jepara. Sehingga hipotesis pertama yang menyatakan "Ada pengaruh yang signifikan antara pendidikan terhadap minat melakukan pencatatan akuntansi", diterima.

Hasil uji hipotesis $t$ didapat nilai sig. 0,740 $>\alpha=0,05$, berarti umur usaha secara parsial tidak mempunyai pengaruh positif signifikan terhadap minat melakukan pencatatan akuntansi pada IKM Kabupaten Jepara. Sehingga hipotesis kedua yang menyatakan "Ada pengaruh yang signifikan antara pendidikan terhadap minat melakukan pencatatan akuntansi", ditolak.

Hasil uji hipotesis $\mathrm{t}$ didapat nilai sig. $0,000<a=0,05$, berarti komitmen secara parsial mempunyai pengaruh positif signifikan terhadap minat melakukan pencatatan akuntansi pada IKM Kabupaten Jepara. Sehingga hipotesis ketiga yang menyatakan "Ada pengaruh yang signifikan antara komitmen terhadap minat melakukan pencatatan akuntansi", diterima.

2. Uji Hipotesis $F$

Uji Hipotesis F digunakan untuk menguji praduga pengaruh antara pendidikan, umur usaha dan komitmen terhadap minat melakukan pencatatan akuntansi pada IKM Kabupaten Jepara secara simultan. Hasil Uji Hipotesis F ditunjukkan pada table 3 berikut:

Tabel 3. Hasil Uji Hipotesis F

\begin{tabular}{|c|c|c|c|c|}
\hline Model & & $\mathrm{df}$ & $\mathrm{F}$ & Sig. \\
\hline & Regression & 3 & 7.320 & $.000^{\mathrm{b}}$ \\
\hline 1 & Residual & 85 & & \\
\hline & Total & 88 & & \\
\hline
\end{tabular}

Sumber : Data primer diolah dengan SPSS Statistics Version 20

Hasil uji hipotesis F didapat nilai sig. 0,000 $<a=0,05$, berarti pendidikan, umur usaha dan komitmen secara simultan mempunyai pengaruh yang signifikan terhadap minat melakukan pencatatan akuntansi pada IKM Kabupaten Jepara. 


\section{Koefisien Determinasi}

Koefisien determinasi merupakan koefisien yang digunakan untuk mengetahui prosentase pendidikan, umur usaha dan komitmen dalam mempengaruhi perubahan minat melakukan pencatatan akuntansi pada IKM Kabupaten Jepara. Hasil analisis koefisien determinasi ditunjukkan pada table 4.

Tabel 4: Hasil Koefisien Determinasi

\begin{tabular}{lccc}
\hline Model & $\mathrm{R}$ & R Square & Adjusted R Square \\
\hline 1 & $.453^{\mathrm{a}}$ & .205 & .177 \\
\hline
\end{tabular}

Sumber : Data primer diolah dengan SPSS Statistics Version 20

Hasil analisis koefisien determinasi $\left(r^{2}\right)$ diketahui sebesar $20,5 \% \quad(0,205 \times 100 \%)$ berarti pendidikan, umur usaha dan komitmen hanya mampu menjelaskan perubahan minat melakukan pencatatan akuntansi pada IKM Kabupaten Jepara sebesar 20,5\%, sedangkan sebagian besar (79,5\%) perubahan minat melakukan pencatatan akuntansi pada IKM Kabupaten Jepara dijelaskan oleh variabel lain di luar penelitian ini.

\section{PEMBAHASAN}

\section{Pengaruh Pendidikan Terhadap Minat Melakukan Pencatatan Akuntansi}

Hasil analisis regresi berganda diketahui pendidikan mempunyai pengaruh positif terhadap minat melakukan pencatatan akuntansi, jadi apabila pendidikan pemilik IKM Kabupaten Jepara semakin tinggi akan meningkatkan minat para pengusaha untuk melakukan pencatatan akuntansi. Sedangkan hasil pengujian hipotesis $t$ diketahui nilai sig. $0,001<a=0,05$, berarti pendidikan secara parsial mempunyai pengaruh positif signifikan terhadap minat melakukan pencatatan akuntansi pada IKM Kabupaten Jepara. Sehingga hipotesis pertama yang menyatakan "Ada pengaruh yang signifikan antara pendidikan terhadap minat melakukan pencatatan akuntansi", diterima. Jadi semakin tinggi pendidikan pengusaha atau pemilik akan dapat meningkatkan minat melakukan pencatatan akuntansi pada IKM Kabupaten Jepara semakin tinggi. Pendidikan mempunyai pengaruh positif signifikan terhadap minat melakukan pencatatan akuntansi dibuktikan dengan responden yang pendidikannya tinggi lebih banyak yang berminat untuk melakukan pencatatan akuntansi untuk perusahaannya dibandingkan dengan responden yang pendidikannya rendah.

Penelitian ini sesuai dengan teori Tarigan (2009) yang menyebutkan bahwa: Pendidikan merupakan sembarang proses yang dipakai individu untuk memperoleh pengetahuan atau wawasan, atau mengembangkan sikap-sikap ataupun keterampilan-keterampilan. Dan Murniati mengemukakan bahwa kemampuan dan keahlian pemilik atau manajer perusahaan kecil dan menengah saat ini sangat ditentukan dari pendidikan formal yang pernah ditempuh. Tingkat pendidikan formal rendah membuat pemilik atau manajer akan rendah penyiapan dan penggunaan informasi akuntansi dibandingkan dengan tingkatan pendidikan formal yang tinggi pemilik atau manajer (Dewi, dkk., 2017).

\section{Pengaruh Umur Usaha Terhadap Minat Melakukan Pencatatan Akuntansi}

Hasil analisis regresi berganda diketahui Umur Usaha (AGE) adalah -0,033, artinya pendidikan mempunyai pengaruh negatif terhadap minat melakukan pencatatan akuntansi, jadi apabila umur usaha IKM Kabupaten Jepara semakin lama akan menurunkan minat para pengusaha untuk melakukan pencatatan akuntansi. Sedangkan hasil pengujian hipotesis $t$ diketahui nilai significant dari variabel Umur Usaha (AGE) sebesar 0,740. Karena nilai sig. 0,740 $>\alpha=0,05$, berarti umur usaha secara parsial tidak mempunyai pengaruh positif signifikan terhadap minat melakukan pencatatan akuntansi pada IKM Kabupaten Jepara. Sehingga hipotesis kedua yang menyatakan "Ada pengaruh yang signifikan antara umur usaha terhadap minat melakukan pencatatan akuntansi", ditolak. Jadi baru atau lama usaha yang dijalani tidak akan meningkatkan minat melakukan pencatatan akuntansi pada IKM Kabupaten Jepara. Tidak adanya mempunyai pengaruh positif signifikan antara umur 
usaha terhadap minat melakukan pencatatan akuntansi pada IKM Kabupaten Jepara, dibuktikan dengan Umur Usaha yang Baru lebih tinggi minatnya untuk melakukan pencatatan akuntansi untuk perusahaannya dibandingkan dengan Umur Usaha yang Lama. Selain itu alasan IKM tidak berminat untuk melakukan pencatatan akuntansi adalah para IKM tidak mau ribet, selama ini sudah jalan ya sudah. Tetapi kalau mereka baru mengalami musibah (seperti kehilangan asset atau barang dagangannya) baru ingin melakukan pencatatan. (hasil wawancara lanjutan dengan Bapak Agus Ismoyo, Pemilik AGS Komputer).

Dalam teori dijelaskan umur menentukan cara berpikir, bertindak dan berperilaku perusahaan dalam melakukan operasionalnya. Selain itu umur mengakibatkan perubahan pola pikir dan tingkat kedewasaan perusahaan tersebut dalam mengambil sikap atas setiap tindakan-tindakannya. Basu dan Waymire menjelaskan Ketika jumlah transaski dalam sebuah usaha semakin lama semakin banyak dan kompleks, ketika itu juga kemampuan otak manusia tidak mampu untuk mengingat semua transaksi yang terjadi karena keterbatasannya sebagai mahkluk yang lemah (Halim, 2013). Munculnya banyak transaksi dalam industri kecil menengah (IKM) menyebabkan semakin banyak transaksi yang harus diingat oleh pengusaha, dan karena keterbatasannya sebagai mahkluk yang lemah, maka dibutuhkan suatu catatan sebagai alat untuk membantu mengingat transaski tersebut, yaitu catatan akuntansi. Dengan demikian umur usaha memungkinkan untuk mendorong pengusaha melakukan pencatatan akuntansi untuk pengelolaan usahanya.

\section{Pengaruh Komitmen Organisasi Terhadap Minat Melakukan Pencatatan Akuntansi}

Hasil analisis regresi berganda diketahui Komitmen Organisasi (COM) adalah 0,375, artinya komitmen organisasi mempunyai pengaruh positif terhadap minat melakukan pencatatan akuntansi, jadi apabila komitmen yang dimiliki IKM Kabupaten Jepara semakin tinggi atau kuat akan meningkatkan minat para pengusaha untuk melakukan pencatatan akuntansi. Sedangkan hasil pengujian hipotesis $t$ diketahui nilai sig. $0,000<\alpha=0,05$, berarti komitmen secara parsial mempunyai pengaruh positif signifikan terhadap minat melakukan pencatatan akuntansi pada IKM Kabupaten Jepara. Sehingga hipotesis ketiga yang menyatakan "Ada pengaruh yang signifikan antara komitmen terhadap minat melakukan pencatatan akuntansi", diterima. Jadi semakin kuat komitmen yang dimiliki organisasi atau perusahaan akan dapat meningkatkan minat melakukan pencatatan akuntansi pada IKM Kabupaten Jepara semakin tinggi. Adanya pengaruh positif signifikan antara komitmen organisasi terhadap minat melakukan pencatatan akuntansi dibuktikan dengan responden yang Komitmen Organisasinya Kuat lebih banyak yang berminat untuk melakukan pencatatan akuntansi untuk perusahaannya dibandingkan dengan responden yang Komitmen Organisasinya Lemah.

Mowday, et al. menunjukkan komitmen organisasional adalah suatu daya dari seseorang dalam mengidentifikasikan keterlibatannya dalam suatu bagian organisasi (Ratifah dan Ridwan, 2012). Komitmen organisasi yang termotivasi melaporkan semua aktivitas dengan cara melaksanakan pencatatan akuntansi untuk menghasilkan informasi dalam bentuk laporan keuangan sebagai wujud akuntabilitas kepada publik. Jadi suatu perusahaan yang memiliki komtimen untuk melakukan perubahan demi berkembangnya perusahaan, akan termotivasi untuk melakukan pencatatan akuntansi supaya dapat memiliki perencanaan yang sistematis dan juga dapat mengendalikan perusahaan dengan baik.

\section{SIMPULAN}

1. Ada pengaruh yang signifikan antara pendidikan terhadap minat melakukan pencatatan akuntansi (sig. 0,001), sehingga pendidikan pemilik IKM semakin tinggi, dapat meningkatkan minat untuk melakukan pencatatan akuntansi. Dari hasil penelitian didapat dari 81 orang berpendidikan tinggi, sebanyak 59 orang yang berminat melakukan pencatatan akuntansi.

2. Tidak ada pengaruh yang signifikan antara umur usaha terhadap minat melakukan pencatatan akuntansi (sig. 0,740), sehingga baru atau lama usaha yang dijalani tidak akan menurunkan atau 
meningkatkan minat melakukan pencatatan akuntansi. Hasil penelitian diketahui sebanyak 35 orang IKM yang umur usahanya baru mempunyai minat melakukan pencatatan akuntansi, sedangkan IKM yang umur usahanya lama yang mempunyai minat melakukan pencatatan akuntansi sebanyak 30 orang. Jadi Umur Usaha Lama tidak dapat dipastikan memiliki minat yang tinggi untuk melakukan pencatatan akuntansi.

3. Ada pengaruh yang signifikan antara komitmen organisasi terhadap minat melakukan pencatatan akuntansi (sig. 0,000), sehingga semakin kuat komitmen yang dimiliki organisasi atau perusahaan akan dapat meningkatkan minat melakukan pencatatan akuntansi. Dari hasil penelitian didapat dari 62 orang yang Komitmen Organisasinya Kuat, sebanyak 50 orang yang berminat melakukan pencatatan akuntansi

\section{SARAN}

1. Karena laporan akuntansi mempunyai manfaat yang sangat besar bagi perusahaan, dan hasil penelitian menunjukkan pendidikan dan komitmen organisasi berpengaruh positif signifikan terhadap minat melakukan pencatatan akuntansi, maka sebaiknya IKM di Kabupaten Jepara seharusnya secepatnya untuk melakukan pencatatan akuntansi. Kalau belum bisa dan tidak mempunyai pengetahuan yang banyak tentang akuntansi, bisa mengikuti pelatihan atau bisa merekrut karyawan yang berkompeten dalam bidang akuntansi.

2. Bagi peneliti selanjutnya, bisa melakukan penelitian lebih lanjut dengan menentukan obyek penelitian yang homogen sehingga hasil penelitian bisa spesifik, dan kebijakan bisa diambil dengan tepat.

\section{DAFTAR PUSTAKA}

Arikunto, S. 2010. Prosedur Penelitian Suatu Pendekatan Praktik. Rineka Cipta. Jakarta.

Bungin, B. 2014. Metodologi Penelitian Kuantitatif (Komunikasi, Ekonomi, dan Kebijakan Publik, Serta

Ilmu-Ilmu Sosial Lainnya). Kencana Prenada Media Group. Jakarta.

Departemen Pendidikan Nasional, 2008. Kamus Bahasa Indonesia. Pusat Bahasa, Jakarta.

Dewi, NAPU., Yuniarta, GA., dan Wahyuni, MA., 2017. Pengaruh Sosialisasi Sak Etap, Tingkat Pendidikan Pemilik, Dan Persepsi Pelaku UKM Terhadap Penggunaan SAK ETAP Pada UKM di Kecamatan Buleleng. Jurusan Akuntansi Program S1, Volume 7 No. 1 Tahun 2017.

Grafiti, AS. , 2014. Minat Pelaku UMKM Untuk Menyusun Laporan Keuangan: Aplikasi Theory of Planned Behavoir (Studi pada UMKM di Wilayah Bandungan). Kertas Kerja Fakultas Ekonomika dan Bisnis UKSW, Salatiga.

Ghozali, I. 2016. Aplikasi Analisis Multivariate Dengan Program IBM SPSS 21 Update PLS Regresi. BP Universitas Diponegoro. Semarang.

Halim, SA., 2013. Faktor-faktor Yang Mempengaruhi Pencatatan Transaksi Pada Usaha Mikro dan Kecil di Kecamatan Sidorejo Kota Salatiga. Kertas Kerja Fakultas Ekonomika dan Bisnis UKSW, Salatiga.

Hanum, Z. 2013. Pengaruh Persepsi Pengusaha Kecil Atas Informasi Akuntansi Keuangan Terhadap Keberhasilan Perusahaan (Survei Pada Usaha-Usaha Kecil Di Kota Medan). Jurnal Riset Akuntansi Bisnis, ISSN : 1693-7597, vol n02 September 2013.

Hasan, I. 2009. Analisis Data Penelitian Dengan Statistik. Bumi Aksara. Jakarta.

Hurlock, E. B., 2009. Alih bahasa Istiwidayanti, Soedjarwo; Editor: Ridwan Max. Psikologi Perkembangan: Suatu Pendekatan Sepanjang Rentang Kehidupan. Erlangga, Jakarta.

Isgiyarta, J. 2009. Teori Akuntansi dan Laporan Keuangan Islami. Badan Penerbit Universitas Diponegoro, Semarang.

Ismail. 2010. Akuntansi Bank. Kencana, Jakarta.

Meinhard, et al. 1987. "Governmental Audits: An Action Plan for Excellence". Jurnal of Accountancy (Juli), pp. 86-91. 
Mowdey, R. T., R. M. Steers and L. W. Porter. 1979. The Measurement of Organizational Commitment. Journal of Vocational Behaviour, 14: 224-247.

Murniati 2002, Investigasi Faktor-Faktor yang Mempengaruhi Penyiapan dan Penggunaan Informasi Akuntansi Perusahaan Kecil dan Menengah, Semarang, SNA V 5-6 September 2002, diakses 20 Maret 2017 dari http://pdeb.fe.ui.ac.id.

Nazir, M. 2011. Metode Penelitian. Ghalia Indonesia. Jakarta.

Pemerintah Daerah Kabupaten Jepara, 2012. Jepara Dalam Angka 2012, Badan Pusat Statistik dan BAPPEDA Kabupaten Jepara.

Pemerintah Daerah Kabupaten Jepara, 2013. Jepara Dalam Angka 2013, Badan Pusat Statistik dan BAPPEDA Kabupaten Jepara.

Pemerintah Daerah Kabupaten Jepara, 2014. Jepara Dalam Angka 2014, Badan Pusat Statistik dan BAPPEDA Kabupaten Jepara.

Pemerintah Daerah Kabupaten Jepara, 2015. Kabupaten Jepara Dalam Angka 2015, Badan Pusat Statistik dan BAPPEDA Kabupaten Jepara.

Pemerintah Daerah Kabupaten Jepara, 2016. Kabupaten Jepara Dalam Angka 2016, Badan Pusat Statistik dan BAPPEDA Kabupaten Jepara.

Ratifah, I. dan Ridwan, M. 2012. Komitmen Organisasi Memoderasi Pengaruh Sistem Akuntansi Keuangan Daerah terhadap Kualitas Laporan Keuangan. Trikonomika, ISSN 1411-514X. Volume 11, No. 1, Juni 2012, Hal. 29-39.

Sitoresmi, LD., dan Fuad, 2013. Faktor-Faktor Yang Mempengaruhi Penggunaan Informasi Akuntansi Pada Usaha Kecil Dan Menengah (Studi Pada KUB Sido Rukun Semarang). Diponegoro Journal Of Accounting. Volume 2, Nomor 3, Tahun 2013, Halaman 1-13. ISSN (Online): 2337-3806.

Sugiyono, 2011. Statistik Untuk Penelitian. Alfabeta. Bandung.

Tarigan, R., 2009. Perencanaan Pembangunan Wilayah. Bumi Aksara, Jakarta.

Waymire, GB., 2009. Exchange Guidance Is The Fundamental Demand For Accounting. The Accounting Review, Volume 84, No. 1, Januari, pp. 53-62 